\title{
Analysis of spatiotemporal characteristics of cultivated land fragmentation in different landform areas in Northeast China
}

\author{
FENGKUI QIAN ${ }^{1}$, Yanru Chi ${ }^{1}$, Rattan $\mathrm{Lal}^{2}$, and K. Lorenz ${ }^{2}$ \\ ${ }^{1}$ Shenyang Agricultural University \\ ${ }^{2}$ The Ohio State University
}

May 5, 2020

\begin{abstract}
Assessing temporal and spatial characteristics of cultivated land fragmentation is necessary to identifying management practices which can reduce the negative environmental effects. Thus, the purpose of this study was to use principal component analysis and spatial autocorrelation to analyze the dynamic characteristics of cultivated land fragmentation in different landform areas in Liaoning Province, China in terms of time and space. An additional objective was to match the changes with the natural and social environment to support the sustainable development of cultivated land fragmentation. The results indicated that the evolutionary trends of cultivated land fragmentation in the central plain area showed a weakening trend, contrary to those observed in the western hilly and the eastern mountainous areas. Moreover, the spatial distribution characteristics of cultivated land fragmentation in the western hilly area were generally "external low internal high" primarily because of the edge density of cultivated land patches. The spatial distribution characteristics of cultivated land fragmentation in the central plain area were generally "external high internal low" primarily because of the number and division of cultivated land patches. The spatial distribution characteristics of cultivated land fragmentation in the eastern mountainous area were generally "south low north high" because of the division of cultivated land patches. These results can provide guidelines for planners, managers, decisionmakers and others to formulate regulatory policies, identify land remediation areas, and promote sustainable development of cultivated land.
\end{abstract}

\section{Hosted file}

Analysis of spatiotemporal characteristics of cultivated land fragmentation in different landform areas available at https://authorea.com/users/301349/articles/431401-analysis-of-spatiotemporalcharacteristics-of-cultivated-land-fragmentation-in-different-landform-areas-innortheast-china

\section{Hosted file}

Figure 1.jpg available at https://authorea.com/users/301349/articles/431401-analysis-ofspatiotemporal-characteristics-of-cultivated-land-fragmentation-in-different-landformareas-in-northeast-china

\section{Hosted file}

Figure 2.jpg available at https://authorea.com/users/301349/articles/431401-analysis-ofspatiotemporal-characteristics-of-cultivated-land-fragmentation-in-different-landformareas-in-northeast-china

\section{Hosted file}


Figure 3.jpg available at https://authorea.com/users/301349/articles/431401-analysis-ofspatiotemporal-characteristics-of-cultivated-land-fragmentation-in-different-landformareas-in-northeast-china

\section{Hosted file}

Figure 4.jpg available at https://authorea.com/users/301349/articles/431401-analysis-ofspatiotemporal-characteristics-of-cultivated-land-fragmentation-in-different-landformareas-in-northeast-china 